\title{
Molecular Diagnostics for the Sigatoka Disease Complex of Banana
}

\author{
Mahdi Arzanlou, Edwin C. A. Abeln, Gert H. J. Kema, Cees Waalwijk, Jean Carlier, \\ Ineke de Vries, Mauricio Guzmán, and Pedro W. Crous
}

First and eighth authors: Laboratory of Phytopathology, Wageningen University, Binnenhaven 5, 6709 PD Wageningen, The Netherlands; first, second, and eighth authors: CBS Fungal Biodiversity Centre, Uppsalalaan 8, 3584 CT Utrecht, The Netherlands; third, fourth, and sixth authors: Plant Research International BV, P.O. Box 16, 6700 AA Wageningen, The Netherlands; fifth author: Centre de Coopération Internationale en Recherche Agronomique pour le Développement (CIRAD), UMR-BGPI, TA41/K, Campus International de Baillarguet 34398 Montpellier Cedex 5, France; and seventh author: CORBANA S.A., P.O. Box 6504-1000 San José, Costa Rica. Accepted for publication 21 March 2007.

\begin{abstract}
Arzanlou, M., Abeln, E. C. A., Kema G. H. J., Waalwijk, C., Carlier, J., de Vries, I., Guzmán, M., and Crous, P. W. 2007. Molecular diagnostics for the Sigatoka disease complex of banana. Phytopathology 97:1112-1118.

The Sigatoka disease complex of banana involves three related ascomycetous fungi, Mycosphaerella fijiensis, M. musicola, and M. eumusae. The exact distribution of these three species and their disease epidemiology remain unclear, because their symptoms and life cycles are rather similar. Disease diagnosis in the Mycosphaerella complex of banana is based on the presence of host symptoms and fungal fruiting structures,

nostic tools for detection and quantification of M. fijiensis, M. musicola, and $M$. eumusae. Conventional species-specific polymerase chain reaction $(\mathrm{PCR})$ primers were developed based on the actin gene that detected DNA at as little as 100, 1 , and $10 \mathrm{pg} / \mu \mathrm{l}$ from M. fijiensis, M. musicola, and $M$. eumusae, respectively. Furthermore, TaqMan real-time quantitative PCR assays were developed based on the $\beta$-tubulin gene and detected quantities of DNA as low as $1 \mathrm{pg} / \mu \mathrm{l}$ for each Mycosphaerella sp. from pure cultures and DNA at $1.6 \mathrm{pg} / \mu \mathrm{l}$ per milligram of dry leaf tissue for $M$. fijiensis that was validated using naturally infected banana leaves.
\end{abstract} which hamper preventive management strategies. In the present study, we have developed rapid and robust species-specific molecular-based diag-
Additional keywords: Mycosphaerella spp., Sigatoka complex.
Banana and plantain (Musa spp.) are among the world's most important staple food crops, ranking fourth after wheat, rice, and corn, with exported banana valued at US\$ 4.5 to 5 billion per year during 1998 to $2000(18,19)$. However, banana plants are prone to a variety of devastating diseases, including Fusarium wilt, caused by $F$. oxysporum f. sp. cubense; banana bunchy top virus; and Mycosphaerella spp.-associated leaf spot diseases. Although several species of Mycosphaerella have been described from banana $(6-8,15)$, three species, namely Mycosphaerella fijiensis (causal agent of black leaf streak disease), M. musicola (causal agent of yellow Sigatoka disease), and M. eumusae (causal agent of eumusae leaf spot disease), cause major economic losses $(9,19)$. These diseases are serious threats for banana production worldwide because they reduce photosynthetic capacity of plants through necrotic leaf lesions, which result in reduced crop yield and fruit quality. Yellow Sigatoka first was described on banana in Java in 1902, and became a serious global disease epidemic during the next 40 years. The disease was especially severe in the Sigatoka Valley in Fiji, where banana plants were sprayed intensively with fungicides to control disease; it also was here that black leaf streak disease first appeared in 1963 (15). Black leaf streak predominantly occurs in lowlands, but at altitudes of $>1,500 \mathrm{~m}$ in Colombia and Costa Rica both pathogens are equally severe (18). M. fijiensis is considered a quarantine organism in many banana-producing areas and continues to occupy new ecological niches, although it is presently still unknown from many countries in Latin America and the Caribbean region. More recently, it has been reported in Trinidad (10), and we have

Corresponding author: G. H. J. Kema; E-mail address: gert.kema@wur.nl

doi:10.1094/PHYTO-97-9-1112

(C) 2007 The American Phytopathological Society confirmed its presence in Grenada in the Caribbean region (J. Carlier and M. Arzanlou, unpublished data). Yellow Sigatoka normally is observed under cooler conditions than black leaf streak disease, and ascospore and conidial germ tubes of M. musicola grow faster at cooler conditions than those of $M$. fijiensis $(14,18)$. Yellow Sigatoka mostly has been replaced by black leaf streak disease in Central America and the coastal areas of the Caribbean, but it remains a considerable problem in subtropical regions $(2,14,18)$. M. fijiensis is more aggressive than M. musicola, and causes premature fruit ripening with losses of 33 to $76 \%(15,18,22)$.

In the mid-1990s, a third Mycosphaerella sp., M. eumusae, was recognized as a new constituent of the Sigatoka complex of banana $(4,9)$. Presently, M. eumusae is known from Southeast Asia and parts of Africa, where it affects cultivars that are highly resistant to both $M$. musicola and M. fijiensis (15). The chronology of disease records around the world suggests that Southeast Asia is the center of origin for all these three species $(15,20)$. Asia is the centre of diversity of banana as well, where earliest domestication of edible banana took place and many wild banana cultivars still grow naturally in the forests (15). Even though $M$. fijiensis has been present in Southeast Asia for a long time, it has not become the dominant pathogen over M. musicola in this region. This might be due to competition among the three species or to the existence of different host populations in this region, which could lead to co-evolution of each species with different host populations in different areas $(3,15,20)$. However, the exact distribution of the three species in this region remains unclear, because their symptoms are rather similar $(9,15)$.

A component of successful plant disease management is early detection of the pathogens that cause the Sigatoka disease complex, encompassing eradication and chemical and quarantine management strategies. Traditionally, diagnosis of the constituent species in the Sigatoka complex was based on disease symptoms, 
which have limited diagnostic value due to their similarity, and the long latent period that varies from 14 to 35 days, depending on weather conditions and cultivar $(2,18)$. Species of Mycosphaerella are distinguished by morphological characteristics that require expertise to distinguish, including ascospore morphology, germination patterns, and minute differences in the morphology of their anamorphs $(5,8)$. Furthermore, traditional diagnosis is time consuming and inappropriate for eradication and quarantine management strategies.

In recent years, conventional polymerase chain reaction (PCR)based techniques have emerged as robust tools for diagnosis and detection of phytopathogenic fungi and have contributed greatly to plant disease management $(12,13,17,25)$. However, postamplification procedures and the presence of chemical elements in plant extracts still prevent the large-scale application of diagnostic PCR in plant pathology. Moreover, in conventional PCR, the amplification efficiency is not consistent during all PCR cycles, and remains unreliable for quantitative analysis $(11,17)$. Real-time PCR alleviates these difficulties because it combines thermal cycling with online fluorescent detection of amplicons. Unlike the end-point PCR, accumulation of amplicons is monitored during all PCR cycles. In real-time PCR reactions, the specific cycle number at which a statistically significant increase in fluorescence can be detected is defined as the threshold cycle $\left(C_{t}\right)$. By definition, the $C_{t}$ value is inversely proportional to the log value of the initial template DNA quantity. Therefore, real-time technology is widely used to detect and quantify DNA from plant pathogens $(17,25)$. This technique enables DNA quantification at very low concentrations ( $\mathrm{pg} / \mathrm{ml})$, and has been applied in quantitative detection of plant pathogens, biological control agents, plant-microbe interaction experiments $(23,24)$, and monitoring studies $(11,21)$.

The aim of the present study was to develop and optimize molecular-based detection and quantification tools for $M$. fijiensis, $M$. musicola, and $M$. eumusae, the primary species of the Sigatoka complex of banana, to further facilitate ecological and epidemiological studies of this diseases complex.

A future goal would be to implement these tools in decision support systems that will be established for disease management.

\section{MATERIALS AND METHODS}

Genomic DNA for PCR analysis. The Mycosphaerella strains as well as fungal species commonly occurring on banana leaves that were used to test primer and probe specificity are listed in Table 1. Genomic DNA was extracted from axenic cultures grown on agar plates using the PureGene kit (Gentra Systems Inc., Minneapolis, MN), whereas the DNeasy Plant Mini Kit (Qiagen, Germany) was used to isolate DNA from uninfected banana leaves as well as banana leaves naturally infected with $M$. fijiensis, M. musicola, or M. eumusae. Genomic DNA was used to test for possible cross reactions and to verify the specificity and efficacy of the real-time PCR primers and probes.

Primers for qualitative PCR. A generally applicable primer pair ACTF/ACTR (Table 2; expected amplicon size 820 bp) was designed and used to generate actin sequences from different Mycosphaerella spp. and other fungi commonly causing leaf spots on banana. Amplification reactions were performed with the ACTF/ACTR primer pair in a total reaction volume of $25 \mu \mathrm{l}$, which was composed of $1 \times$ PCR buffer (Applied Biosystems, Foster City, CA), $1.5 \mathrm{mM} \mathrm{MgCl} 2,60 \mu \mathrm{M}$ dNTPs, $0.2 \mu \mathrm{M}$ ACTF and ACTR primers, $1.5 \mathrm{U}$ of Taq DNA polymerase (Roche Diagnostics, Indianapolis, IN), and 1 ng of genomic DNA. PCR cycle conditions were $5 \mathrm{~min}$ of $95^{\circ} \mathrm{C}$; followed by 36 cycles of $94^{\circ} \mathrm{C}$ for $30 \mathrm{~s}, 60^{\circ} \mathrm{C}$ for $30 \mathrm{~s}$, and $72^{\circ} \mathrm{C}$ for $60 \mathrm{~s}$; and a final elongation at $72^{\circ} \mathrm{C}$ for $7 \mathrm{~min}$. PCR amplicons were sequenced using Amersham Dye chemistry (Amersham Biosciences). Primers for conventional PCR were designed based on sequence alignment of the actin gene for the 17 Mycosphaerella spp. associated with the Sigatoka leaf spot disease complex of banana: 6 known species (Table 1) and 11 undescribed Mycosphaerella spp. (M. Arzanlou, unpublished data). Species-specific primer combinations were designed with expected amplicon sizes of $500 \mathrm{bp}$ from $M$. fijiensis (ACTR/MFactF), $200 \mathrm{bp}$ from M. musicola (MMactF2/MMactRb), and $630 \mathrm{bp}$ for M. eumusae (ACTF/MEactR).

Multiplex PCR. Specific primers for each species were used in combination with the $\beta$-tubulin gene primer set, TMG3F/TMG4 (Table 2), as an internal control to confirm that a fungus was the causal organism of the leaf spot. Specificity and cross reactions of these primer sets were verified on DNA extracted from uninfected or naturally infected banana leaves as well as from fungal species frequently occurring on banana (Table 1). The PCR amplification was performed under the same conditions as used with the ACTF/ACTR primer set.

Primer and probe design for quantitative PCR. Primer and probe sets for real-time PCR assays were designed based on partial sequences of the $\beta$-tubulin gene. Primer set TMG3/TMG4 (Table 2) was used to amplify part of the $\beta$-tubulin gene in the Mycosphaerella spp. listed in Table 1 and the 11 additional, though unnamed, Mycosphaerella spp. associated with the Sigatoka disease complex (M. Arzanlou, unpublished data). Primers and probes were designed manually and then evaluated with Beacon Designer 4.01 software (Premier Biosoft International; available online). One probe and primer combination was designed for $M$. fijiensis and a common probe was designed for $M$. musicola and $M$. eumusae in combination with selective primers for these two species (Table 2). Both probes were labeled with 6-carboxyfluorescein (FAM) at the $5^{\prime}$ end and drake deep quencher dye at the $3^{\prime}$ end (Eurogentec, Belgium). A Potato leafroll virus (PLRV) probe was used as a positive internal control to discriminate between uninfected samples and false negatives due to possible PCR inhibitors (25).

Real-time PCR was performed using a MicroAmp Optical 96-well reaction plate and MicroAmp Optical Caps (Applied Biosystems). An ABI Prism 7700 Sequence Detection System (Applied Biosystems) was used to perform the PCR and assess

TABLE 1. Mycosphaerella strains and other fungi isolated from Musa included in this study

\begin{tabular}{|c|c|c|}
\hline Fungus species & Isolate $^{\mathrm{a}}$ & Geographical origin \\
\hline Mycosphaerella fijiensis & $\mathrm{X} 845$ & Indonesia \\
\hline M. fijiensis & X848 & New Caledonia \\
\hline M. fijiensis & X842 & Costa Rica \\
\hline M. fijiensis & X841 & Colombia \\
\hline M. fijiensis & X843 & Honduras \\
\hline M. fijiensis & CIRAD89 & Gabon \\
\hline M. musicola & X858 & Australia \\
\hline M. musicola & X862 & Cameroon \\
\hline M. musicola & X856 & Martinique \\
\hline M. musicola & X954 & Costa Rica \\
\hline M. musicola & X62 & Wind Ward Isles \\
\hline M. musicola & CIRAD318 & Unknown \\
\hline M. eumusae & X871 & India \\
\hline M. eumusae & X869 & Sri Lanka \\
\hline M. eumusae & S1037D & Mauritius \\
\hline M. eumusae & S1037E & Mauritius \\
\hline M. eumusae & S1031B & Mauritius \\
\hline M. eumusae & CIRAD670 & Vietnam \\
\hline M. musae & X38 & Mozambique \\
\hline M. lateralis & X1023 & India \\
\hline M. thailandica & X881 & Martinique \\
\hline Cordana musae & CBS 151.34 & Unknown \\
\hline C. johnstonii & X1071 & Indonesia \\
\hline Metulocladosporiella musae & CBS 161.74 & Honduras \\
\hline Metulocladosporiella musicola & CBS 113862 & Kenya \\
\hline
\end{tabular}

a Strains maintained at the Centraalbureau voor Schimmelcultures (CBS), Utrecht, The Netherlands. 
fluorescence. Each amplification reaction consisted of $1 \mathrm{ng}$ of genomic DNA, $1 \times$ real-time PCR buffer (Applied Biosystems), $5 \mathrm{mM} \mathrm{MgCl}_{2}, 83 \mathrm{nM}$ FAM-labeled TaqMan probe, $83 \mathrm{nM}$ VIClabeled PLRV probe, 1.5 U of Hot Gold star DNA polymerase (Eurogentec), $333 \mathrm{nM}$ forward and reverse primer for each target DNA, and the positive PLRV internal control in a reaction volume of $30 \mu \mathrm{l}$. In each assay, nontemplate DNA and uninfected banana DNA templates were run in parallel as negative controls. The thermocycling profile for conventional diagnostic PCR consisted of an initial incubation of $2 \mathrm{~min}$ at $50^{\circ} \mathrm{C}$ followed by incubation of $10 \mathrm{~min}$ at $95^{\circ} \mathrm{C}$ and 40 cycles of $15 \mathrm{~s}$ at $95^{\circ} \mathrm{C}$ and $1 \mathrm{~min}$ at $60^{\circ} \mathrm{C}$.

Standard curves. To calculate the amount of fungal biomass in field samples, a standard regression curve was made using serial dilutions of pure genomic DNA of M. fijiensis, M. musicola, and M. eumusae in distilled water $(10,000,1,000,100,10$, and $1 \mathrm{pg} / \mu \mathrm{l})$. Samples without DNA template and uninfected banana DNA template served as negative controls. Standard regression curves for each species were constructed by plotting the log of the known amount of DNA versus the $C_{t}$ values measured by SDS 7700 software (Applied Biosystems). Serial dilutions were included in each new run and used to calculate the amount of fungal biomass in naturally infected banana leaves.

Validation of TaqMan real-time assay. Infected plant material was used to test the sensitivity of TaqMan primers and probes; namely, artificially inoculated banana leaves (detached leaf inoculation) and naturally infected field samples. For artificial inoculation, isolates of M. fijiensis, M. musicola, and M. eumusae were inoculated individually or in a three-way mixture onto banana leaves of cv. Grand Naine (AAA, Cavendish subgroup) using a detached leaf assay. These banana plants were initiated from tissue culture and grown in a glasshouse for 5 to 7 months. Leaf pieces $(6$ by $6 \mathrm{~cm}$ ) were cut from the youngest, fully mature leaf and placed in petri dishes with the adaxial surface on the medium ( $0.4 \%$ water agar and $50 \mathrm{ppm}$ benzimidazole) (Sigma). M. fijiensis isolate CIRAD89, M. musicola isolate CIRAD318, and $M$. eumusae isolate CIRAD670 were cultured at $20^{\circ} \mathrm{C}$ for 10 to 14 days under continuous and cool-white fluorescent light at $60 \mu \mathrm{mol} \mathrm{m} 2 / \mathrm{s}$ on modified V8-juice medium ( $100 \mathrm{ml}$ of $\mathrm{V} 8$ juice, $0.2 \mathrm{~g}$ of $\mathrm{CaCo}_{3}$, and $20 \mathrm{~g}$ of agar per liter of medium, $\mathrm{pH}$ 6) to initiate conidiation. Water was used to dislodge conidia from the culture and the resulting suspension was adjusted to 3,000 conidia/ml with each isolate at 1,000 conidia/ml for the mixtures (1), and subsequently, $1 \mathrm{ml}$ was used to inoculate each leaf fragment with an artist's airbrush (Badger airbrush no. 150-1-M). Two leaf pieces in two replicates were used for each treatment. Water-sprayed leaf fragments were used as controls. After inoculation, leaf fragments were incubated at $25^{\circ} \mathrm{C}$ with a $12-\mathrm{h}$ photoperiod (4,000 lux) for symptom expression. For each treatment, two leaf pieces were collected at 10 and 30 days after inoculation and stored at $-20^{\circ} \mathrm{C}$. Leaf pieces were lyophilized and ground to a fine powder, and $10 \mathrm{mg}$ were used to extract DNA using the DNeasy Plant Mini Kit (Qiagen) according to the recommendations of the manufacturer. Each sample was analyzed in two replicates in a single run.

To validate TaqMan real-time assays on field samples, we used naturally infected banana leaves with black leaf streak symptoms. Samples (three to six leaf pieces with early and advanced symptoms) were collected from nine banana fields in Costa Rica at different altitudes (Table 3). Sample preparation and DNA extraction were performed as explained above for artificially inoculated leaves and analyzed using the $M$. fijiensis (the major pathogen in the region) primer and probe set in three different runs. The data were analyzed using a $t$ student test to evaluate the statistical significance between treatments $(95 \%$ confidence interval, $\alpha=$ 0.05).

Reproducibility of real-time PCR assays. Different sources of variation that could influence real-time PCR efficiency were evaluated using banana leaves that were naturally infected with M. fijiensis, M. musicola, or M. eumusae. The identity of the Mycosphaerella spp. on these leaves was determined after isolation using morphological characters and was confirmed by sequencing the $\beta$-tubulin gene. Samples represented $10-\mathrm{cm}^{2}$ leaf pieces, 10 of which were selected for each treatment. We determined (i) intra-assay accuracy, influenced by well-to-well differences in signal measurements, pipetting, and PCR efficiency; (ii) inter-assay variability, that may be due to quantitative differences in reaction components among runs, and (iii) intersample reproducibility, which could be affected by differences in sample selection, DNA extraction efficiency, or amplification efficacy

TABLE 3. Sources of field samples used for validation of real-time polymerase chain reaction assays developed in this study

\begin{tabular}{lcll}
\hline Locality & Altitude $(\mathrm{m})$ & Cultivar & Country \\
\hline La Rita & 100 & Cavendish & Costa Rica \\
Siquires & 100 & Gros Michel & Costa Rica \\
Catie & 620 & Cavendish & Costa Rica \\
Tres Equis & 650 & Gros Michel & Costa Rica \\
Santa Marta & 700 & Plantain & Costa Rica \\
Verbena & 1,110 & Gros Michel & Costa Rica \\
La Victoria & 1,240 & Plantain & Costa Rica \\
Cervantes & 1,340 & Gros Michel & Costa Rica \\
San Luis & 1,360 & Cavendish & Costa Rica \\
\hline
\end{tabular}

TABLE 2. Conventional and real-time polymerase chain reaction primers and probes designed and used in this study

\begin{tabular}{|c|c|c|c|}
\hline Identifier & Sequence $\left(5^{\prime} \rightarrow 3^{\prime}\right)$ & Target & Location \\
\hline \multicolumn{4}{|l|}{ Primers } \\
\hline $\mathrm{ACTF}^{\mathrm{a}}$ & TCCAACCGTGAGAAGATGAC & General & Actin \\
\hline $\mathrm{ACTR}^{\mathrm{a}}$ & GCAATGATCTTGACCTTCAT & General & Actin \\
\hline MFactF & CTCATGAAGATCTTGGCTGAG & Mycosphaerella fijiensis & Actin \\
\hline MMactF2 & ACGGCCAGGTCATCACT & M. musicola & Actin \\
\hline MMactRb & GCGCATGGAAACATGA & M. musicola & Actin \\
\hline MEactR & GAGTGCGCATGCGAG & M. eumusae & Actin \\
\hline $\mathrm{TMG}^{\mathrm{a}}$ & CTTTCTGGCAGACCATCTCC & General & $\beta$-tubulin \\
\hline $\mathrm{TMG}^{\mathrm{a}}$ & AAGAGCTGACCGAAAGGAACC & General & $\beta$-tubulin \\
\hline MFBF & CGACACAGCAAGAGCAGCTTC & M. fijiensis & $\beta$-tubulin \\
\hline MFBRtaq & TTCGAAAGCCTTGGCACTTCAA & M. fijiensis & $\beta$-tubulin \\
\hline MMBF & CACACATCAAGAGCAGCACAG & M. musicola & $\beta$-tubulin \\
\hline MMBRtaq & TGGCACTTGGCGGAAGTTTG & M. musicola & $\beta$-tubulin \\
\hline MEBFtaq & CACCTCAAGAGCAGGAGTGGAA & M. eumusae & $\beta$-tubulin \\
\hline MEBRtaq & TTGGCAATTGGAGGTAGTTGTCC & M. eumusae & $\beta$-tubulin \\
\hline \multicolumn{4}{|c|}{ 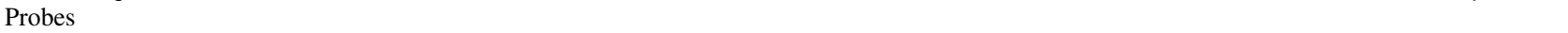 } \\
\hline MFBP & CTGAGCACGACTGACCACAACGCA & M. fijiensis & $\beta$-tubulin \\
\hline FMEP & CACGTCTGATCTCCAGCTCGAGCGCATG & M. musicola and M. eumusae & $\beta$-tubulin \\
\hline
\end{tabular}

${ }^{a}$ Resulted in amplified products for all taxa listed in Table 1. 
among different samples $(23,26)$. One sample of each Mycosphaerella sp. was analyzed in 12 replicates in a single assay to evaluate the intra-assay accuracy. To evaluate the inter-assay variability, the same DNA samples were analyzed in five replicates over three separate assays. The third source of variation was assessed on DNA extracted from eight leaf samples for each of the three Mycosphaerella spp.

\section{RESULTS}

Qualitative and quantitative PCR assays. Primer set TMG3/ TMG4 amplified part of the $\beta$-tubulin gene from the Mycosphaerella spp. listed in Table 1, and no amplicon was obtained when Musa DNA was used as template (data not shown). Sequence alignment of amplicons showed unique sites for each species, which enabled us to design species-specific primers and probes.

Primers for conventional PCR. An actin sequence from an M. graminicola expressed sequence tag (EST) database (16) was used to design a generally applicable primer pair, ACTF/ACTR, that was used to generate actin sequences from six Mycosphaerella spp. known from banana (Table 1) and 11 additional unnamed Mycosphaerella spp. (M. Arzanlou, unpublished data). This primer set resulted in an 820-bp amplicon. Alignment of these sequences enabled the design of three Mycosphaerella species-specific primer sets: ACTR/MFactF amplified a 500-bp

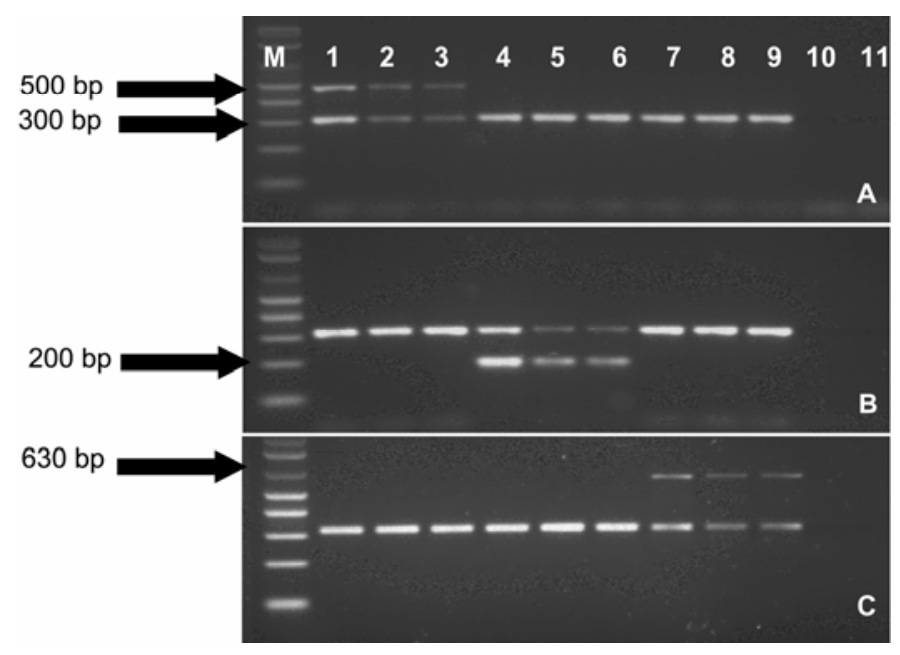

Fig. 1. Amplification results with species-specific primer sets in combination with a positive internal control (TMG3/TMG4) using template DNA from $\mathbf{A}$, Mycosphaerella fijiensis (ACTR/MFactF), B, M. musicola (MMactF2/ $\mathrm{MMactRb}$ ), and C, M. eumusae (MEactR/ ACTF). Genomic DNA from pure cultures of $M$. fijiensis, M. musicola, and M. eumusae (lanes 1, 4, and 7, respectively) and naturally infected banana with $M$. fijiensis (lanes 2 and 3), M. musicola (lanes 5 and 6), M. eumusae (lanes 8 and 9), and banana (lane 10); lane 11 = negative control (water and no template DNA); $\mathbf{M}=$ DNA marker (1-kb plus).
DNA fragment from $M$. fijiensis, MMactF2/MmactRb amplified a 200-bp DNA fragment from M. musicola, and ACTF/MEactR amplified a 630-bp DNA fragment from M. eumusae (Table 2; Fig. 1). Each PCR reaction was performed in combination with the $\beta$-tubulin primer set (TMG3F/TMG4) as a universal fungal internal control to check whether a fungal agent was responsible for the disease symptom (Fig. 1). The specific primer sets for $M$. fijiensis, M. musicola, and M. eumusae also were tested against the naturally infected banana leaves (field samples) and resulted in the expected diagnostic bands (Fig. 1). The sensitivity of the primer sets enabled reliable detection of $M$. fijiensis DNA as low as $100 \mathrm{pg}$ whereas, for M. musicola and M. eumusae, a higher sensitivity was achieved of 1 and $10 \mathrm{pg}$ of genomic DNA, respectively (Fig. 2).

Real-time PCR. In order to quantify the fungal biomass in positively diagnosed diseased leaves, we developed real-time probe and primer sets for the three Mycosphaerella spp. The aforementioned $\beta$-tubulin primer set TMG3F/TMG4 did not enable the design of species-specific primers for conventional PCR assays but was used successfully to design a TaqMan realtime assay primer and probe because it amplified 330-bp fragments from the Mycosphaerella spp. listed in Table 1. The species-specific real-time PCR primers that we designed produced unique amplicons from the target species; a 134-bp amplicon obtained from $M$. fijiensis using primer set $\mathrm{MFBF} /$ MFBRtaq; primer set MMBF/MMBRta produced a 142-bp amplicon from $M$. musicola and primer set MEBFtaq/MEBRtaq yielded a 134-bp amplicon from M. eumusae. In TaqMan realtime assays, the $M$. fijiensis-specific primer set was used in combination with the MFBP probe, which is specific for this species. For M. musicola and M. eumusae, the species-specific primer set for each species was used in combination with the common FMEP probe (Table 2). The fluorescence signals measured for nontarget species and nontemplate DNA controls were all at the base line $\left(C_{t}=40\right)$, whereas the fluorescence signals for the target species passed the baseline threshold at $\mathrm{C}_{\mathrm{t}}=$ 24 for M. fijiensis, $\mathrm{C}_{\mathrm{t}}=22$ for M. musicola, and $\mathrm{C}_{\mathrm{t}}=24$ for M. eumusae. The real-time PCR assay enabled the detection of $1 \mathrm{pg}$ of DNA for each Mycosphaerella sp. The standard curves were generated by plotting the $C_{t}$ values against the log of the known amounts of serially diluted DNA in distilled water, which resulted in linear relationships for each Mycosphaerella sp. For M. fijiensis, the $R^{2}$ was 0.99 , with a PCR efficiency value of $88.34 \%$ (Fig. 3); for M. musicola, the $R^{2}$ value was 0.99 , with a PCR efficiency value of $110 \%$; and, for $M$. eumusae, the $R^{2}$ was 0.99 , with a PCR efficiency value of $87 \%$ (data not shown).

Validation of TaqMan real-time assay. Each primer and probe set was used to amplify DNA from all target species in separate and mixed reactions without any undesired cross-reaction with nontarget species (data not shown). Each primer and probe specifically detected the target species and was sensitive to detect the target species within 10 days post inoculation (dpi). However, quantitative analysis on the detached leaf material was not

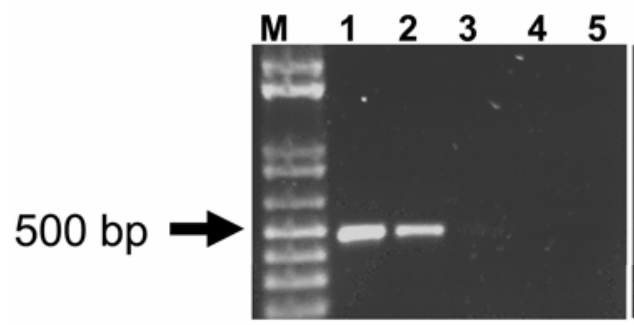

A

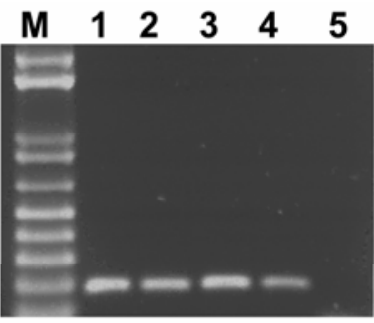

B

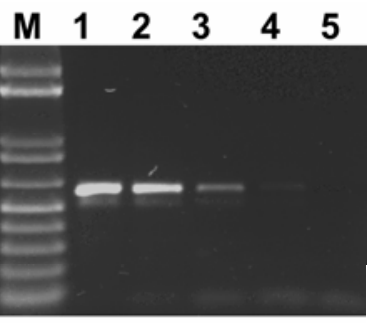

C

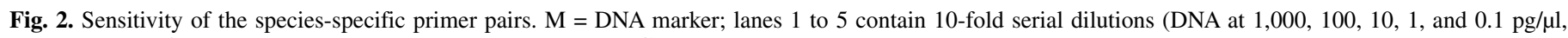
respectively) of $\mathbf{A}$, Mycosphaerella fijiensis, B, M. musicola, and C, M. eumusae. 
reliable, which apparently was due mainly to the artificial inoculation of detached leaves. The quantitative data obtained were inconsistent between replicates of each treatment. A considerable amount of variation was observed in the fungal biomass detected between different replicates of each treatment in mixed and separate inoculations. In order to validate the efficacy of primers and probes, we subsequently collected and analyzed naturally infected black leaf streak field samples. The results obtained from these field sample analyses further confirmed the efficacy of primers and probes developed in this study. The M. fijiensis primer and probe set detected and quantified biomass as low as $1.6 \mathrm{pg}$ of target DNA per milligram dry weight of leaf tissue (Fig. 4). There was a significant difference $(P=0.056)$ in fungal biomass between early and advanced symptoms, which supports the sensitivity of the quantification tool (Fig. 4).

Reproducibility of real-time assays. Banana leaves naturally infected with $M$. fijiensis, M. musicola, and M. eumusae were used to test the reproducibility of the TaqMan real-time assay. The intra-assay values revealed very low standard deviations among the repeats (the mean $\mathrm{C}_{\mathrm{t}}$ values for $M$. fijiensis, $M$. musicola, and M. eumusae were $23 \pm 0.77,22.4 \pm 0.31$, and $24 \pm 0.8$, respectively) (Fig. 5). The inter-assay experiments, testing the reproducibility within the same experiment in different runs, also produced consistent results with low standard deviations (the mean $\mathrm{C}_{\mathrm{t}}$ values for $M$. fijiensis, M. musicola, and M. eumusae

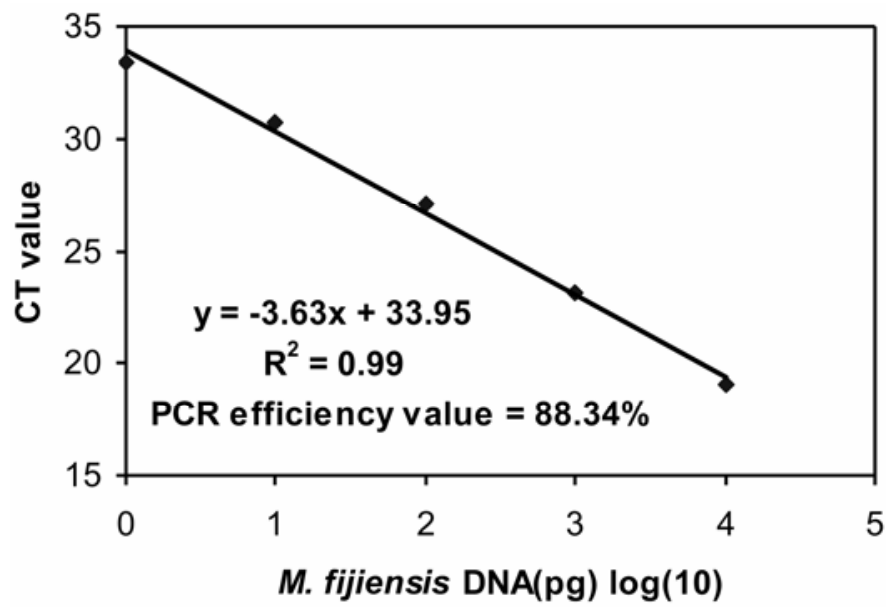

Fig. 3. Standard curve regression between the threshold cycle $\left(C_{t}\right)$ values and the log of known amounts of Mycosphaerella fijiensis DNA. Such curves were developed using purified fungal DNA in each assay in order to estimate the amount of fungal DNA in naturally infected leaves. The polymerase chain reaction $(\mathrm{PCR})$ efficiency value was calculated using the following formula: efficiency $=-1+10^{(-1 / \text { slope })}$. were $22.7 \pm 0.93,22.5 \pm 0.22$, and $23 \pm 0.7$, respectively). As expected, standard deviations from the intersample reproducibility test were higher than the above mentioned assays (the mean $\mathrm{C}_{\mathrm{t}}$ values for $M$. fijiensis, $M$. eumusae, and $M$. musicola were $21.5 \pm 1.4,23.5 \pm 1.4$, and $25 \pm 1.7$, respectively).

\section{DISCUSSION}

Understanding the banana Sigatoka disease complex is a challenge for plant pathologists. Knowledge about the identity of the Mycosphaerella spp. and their distribution in banana-producing areas as well as on specific host-pathogen interactions should enhance the ability of pathologists to understand the dynamics of these pathogens and, thereby, allow better management of this disease complex.

Our primary aim was to develop a rapid and robust detection tool with the feasibility of wide application. Even though a PCRbased detection tool has been developed previously (13), those primes could only differentiate $M$. fijiensis from $M$. musicola. Therefore, we developed and optimized qualitative and quantitative molecular diagnostics sets for the three dominant Mycosphaerella spp. currently recognized in the Sigatoka complex on banana. We successfully developed species-specific primers for

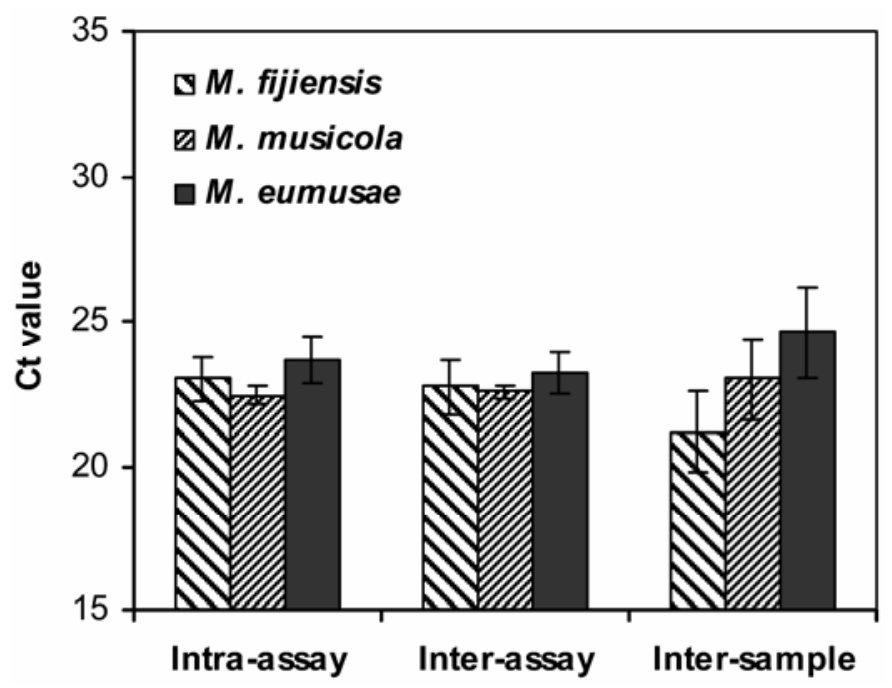

Fig. 5. Assessment of inter-assay, intra-assay, and intersample variability using DNA extracted from banana leaves naturally infected with Mycosphaerella fijiensis, $M$. musicola, and $M$. eumusae. Values are the average of replications (12 replicates in a single run for intra-assay; five replicates in three repeated experiments for inter-assay, and eight DNA samples in a single run for the intersample assay); bars show the standard deviation values.

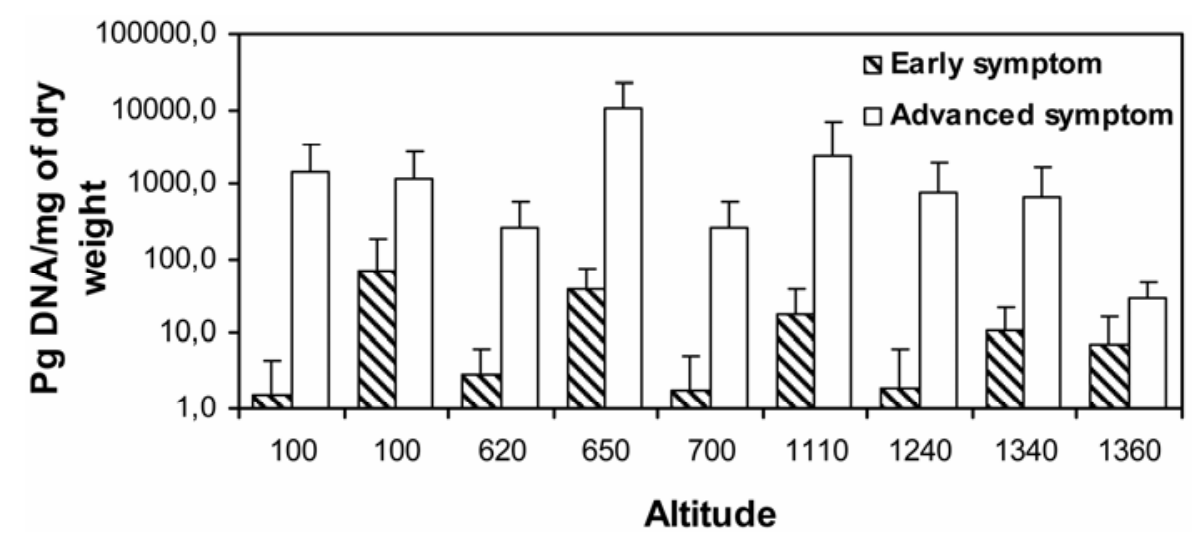

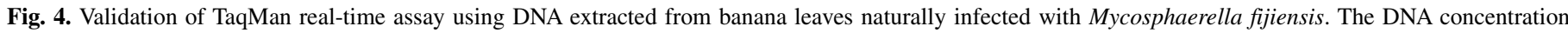

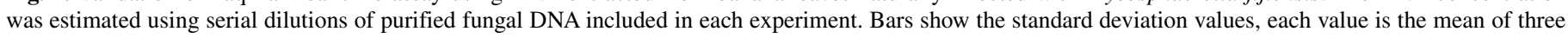
to six independently sampled leaves. 
conventional diagnostic PCR assays for $M$ fijiensis, $M$. musicola, and $M$. eumusae that differentiate these species from each other and from other fungal species commonly occurring on banana leaves (M. Arzanlou, unpublished data) without any undesired cross-reaction.

Selective primers for quantitative TaqMan assays were designed based on sequence data of the $\beta$-tubulin gene that provided unique sites to design the selective primer and probe sets for TaqMan real-time PCR with an expected amplicon size of $\leq 142 \mathrm{bp}$. These very short amplicons $(\leq 142 \mathrm{bp})$ could not be used for conventional PCR because they cannot be visualized on agarose gels, but are suitable for TaqMan quantification assays, because amplification is monitored by the level of florescence. Each primer and probe set resulted in specific detection for the target species. Inclusion of sequence data from up to 11 unnamed Mycosphaerella spp. occurring on banana leaves (M. Arzanlou, unpublished data) in the alignment ensured specificity of each primer and probe set designed for the quantification assay.

The Sigatoka complex on banana used to be limited to M. musicola, M. fijiensis, and, more recently, M. eumusae. Given the emergence of $M$. eumusae and the occurrence of many novel, cryptic Mycosphaerella spp. on banana (M. Arzanlou, unpublished data), there is an urgent need for a robust, reliable, and sensitive PCR primer set to detect and differentiate these commonly occurring three species from each other as well as from new, additional Mycosphaerella spp. Despite the fact that conventional PCR offers the advantage of being simple and relatively cheap per reaction, it is inappropriate for quantitative studies and time consuming in large-scale application. TaqMan real-time PCR assays, as developed in this study, facilitate the quantification of fungal DNA, even when present in very low amounts. Hence, TaqMan assays can support ecological and epidemiological studies by quantifying the effect of agronomical measures such as fungicide applications, the efficacy of biological control agents, and host resistance on fungal biomass development $(11,21,23,24)$.

The reproducibility of the real-time assays developed in this study was excellent. As expected, intersample variation affects the reproducibility of real-time assays, which can be due to differences in sample selection, DNA extraction, and PCR efficacy, emphasizing the importance of optimal sampling strategies (23).

Biomass quantification in real-time assays is based on calibrated standard curves. These curves can be constructed by using serial dilutions of known amounts of fungal DNA in distilled water (25) or in host DNA (23). The latter may be useful to compensate for any possible effect of host DNA on the efficiency of the PCR reactions. Because no such effect was observed, we used standard curves based on serial DNA dilutions of the target species in distilled water. Our assays showed that each primer and probe set could detect quantities of DNA as low as $1 \mathrm{pg} / \mu \mathrm{l}$ for each Mycosphaerella sp. from pure culture. Our results confirmed each primer and probe as being specific, detecting the target species at $10 \mathrm{dpi}$ without any undesired cross-reactivity in separate and mixed inoculations. However, quantification of fungal biomass using artificially inoculated banana leaves (detached leaf assay) was not reliable. The quantification results were inconsistent, because significant variation was observed between different replicates of each treatment. Nevertheless, the results obtained from analyzing field samples showed a minimum detection level of DNA at $1.6 \mathrm{pg} / \mathrm{mg}$ of dry leaf tissue for M. fijiensis, which confirms the high sensitivity of the detection tool. Our data suggest that the detached leaf inoculation method is unsuitable for quantification studies. This might be due to the semibiotrophic nature of Mycosphaerella pathogens of banana, which requires the host plant to be in optimal condition to facilitate disease development. The validation on field samples from Costa Rica was successful and further confirmed the presence of $M$. fijiensis at higher altitudes, which indicates that $M$. fijiensis has the ability for adaptation to cooler conditions, suggesting that it might pose a potential threat for banana cultivation in subtropical countries.

The molecular-based detection and quantification tools developed and optimized in this study are good starting points for the better understanding of the Sigatoka disease complex of banana. The probe and primer sets we designed will facilitate further ecological and epidemiological studies on the Mycosphaerella pathogens of banana.

\section{ACKNOWLEDGMENTS}

Mahdi Arzanlou was funded by the Ministry of Science, Research and Technology of Iran, which we gratefully acknowledge. We thank I. Buddenhagen (University of California, Davis) for some of the infected banana materials used in this study, the Dutch Mycosphaerella group for valuable discussions and support, and CORBANA S.A., San José, Costa Rica for advice and scientific interaction.

\section{LITERATURE CITED}

1. Abadie C., Pignolet, L., Elhadrami, A., Habas, R., Zapater, M. F., and Carlier, C. 2005. Inoculation avec Mycosphaerella sp., agent de cercosporioses, de fragments de feuilles de bananiers maintenus en survie. Pages 131-134 in: Numéro spécial. Méthodes d'appréciation du comportement variétal vis-à-vis des bioagresseurs. Cahier des Techniques de l'INRA.

2. Balint-Kurti, P. J., May, G. D., and Churchill, A. C. L. 2001. Development of a transformation system for Mycosphaerella pathogens of banana: A tool for the study of host/pathogen interactions. FEMS Microbiol. Lett. 195:9-15.

3. Carlier, J., Foure, F., Gauhl, F., Jones, D. R., Lepoivre, P., Mourichon, X., Pasberg-Gauhl, C., and Romero, R. A. 2000. Black leaf streak. Pages 3747 in: Disease of Banana, Abaca and Enset. R. D. Jones, ed. CABI Publishing, Wallingford, UK.

4. Carlier, J., Zapater, M. F., Lapeyre, F., Jones, D. R., and Mourichon, X. 2000. Septoria leaf spot of banana: A newly discovered disease caused by Mycosphaerella eumusae (anamorph Septoria eumusae). Phytopathology 90:884-890.

5. Crous, P. W. 1998. Mycosphaerella spp. and their anamorphs associated with leaf spot diseases of Eucalyptus. Mycol. Mem. 21:1-170.

6. Crous, P. W., and Groenewald, J. Z. 2005. Hosts, species and genotypes: opinions versus data. Aust. Plant Pathol. 34:463-470.

7. Crous, P. W., Groenewald, J. Z., Aptroot, A., Braun, U., Mourichon, X., and Carlier, J. 2002. Integrating morphological and molecular data sets on Mycosphaerella, with specific reference to species occurring on Musa. Pages 34-57 in: Proc. 2nd Int. Workshop on Mycosphaerella Leaf Spot Disease of Bananas. INIBAP, Montpellier, France.

8. Crous, P. W., Groenewald, J. Z., Pongpanich, K., Himaman, W., Arzanlou, M., and Wingfield, M. J. 2004. Cryptic speciation and host specificity among Mycosphaerella spp. occurring on Australian Acacia species grown as exotics in the tropics. Stud. Mycol. 50:457-469.

9. Crous, P. W., and Mourichon, X. 2002. Mycosphaerella eumusae and its anamorph Pseudocercospora eumusae spp. nov.: causal agent of eumusae leaf spot disease of banana. Sydowia 54:35-43.

10. Fortune, M. P., Gosine, S., Chow, S., Dilbar, A., Hill, A. S., Gibbs, H., and Rambaran, N. 2005. First report of black Sigatoka disease (causal agent Mycosphaerella fijiensis ) from Trinidad. Plant Pathol. 54:246.

11. Hietala, A. M., Eikenes, M., Kvaalen, H., Solheim, H., and Fossdal, C. G. 2003. Multiplex real-time PCR for monitoring Heterobasidion annosum colonization in Norway spruce clones that differ in disease resistance. Appl. Environ. Microbiol. 69:4413-4420.

12. Johanson, A., Crowhurst, R. N., Rikkerink, E. H. A., Fullerton, R. A., and Templeton, M. D. 1994. The use of species-specific DNA probes for the identification of Mycosphaerella fijiensis and M. musicola, the causal agents of Sigatoka disease of banana. Plant Pathol. 43:701-707.

13. Johanson, A., and Jeger, M. J. 1993. Use of PCR for detection of Mycosphaerella fijiensis and M. musicola, the causal agents of Sigatoka leaf spot in banana and plantain. Mycol. Res. 97:670-674

14. Jones, R. D. 2000. Sigatoka leaf spots. Pages 79-92 in: Disease of Banana, Abaca and Enset. R. D. Jones, ed. CABI Publishing, Wallingford, UK.

15. Jones, R. D. 2002. The distribution and importance of the Mycosphaerella leaf spot diseases of banana. Pages 25-42 in: Proc. 2nd Int. Workshop on Mycosphaerella Leaf Spot Disease of Bananas. INIBAP, Montpellier, France.

16. Kema, G. H. J., Verstappen, E., van der Lee, T., Mendes, O., Sandbrink, H., Klein-Lankhorst, R., Zwiers, L., Csukai, M., Baker, K., and Waalwijk, 
C. 2003. Gene hunting in Mycosphaerella graminicola. Page 252 in: Proc. 22nd Fungal Genet. Conf. Genetics Socuiety of America (GSA), Bethesda, MD.

17. Lievens, B., and Thomma, B. P. H. J. 2005. Recent developments in pathogen detection arrays: Implications for fungal plant pathogens and use in practice. Phytopathology 95:1374-1380.

18. Marin, D. H., Romero, R. A., Guzmán, M., and Sutton, T. B. 2003. Black Sigatoka an increasing threat to banana cultivation. Plant Dis. 87:208-222.

19. Ploetz, R. 2000. Black Sigatoka. Pestic. Outlook 11:19-23.

20. Rivas, G. G., Zapater, M. F., Abadie, C., and Carlier, J. 2004. Founder effects and stochastic dispersal at the continental scale of the fungal pathogen of bananas Mycosphaerella fijiensis. Mol. Ecol. 13:471-482.

21. Rohel, E. A., Laurent, P., Fraaije, B., Cavelier, N., and Hollomon, D. W. 2002. Quantitative PCR monitoring of the effect of azoxystrobin treatments on Mycosphaerella graminicola epidemics in the field. Pestic. Manage. Sci. 58:248-254.

22. Romero, R. A., and Sutton, T. B. 1997. Sensitivity of Mycosphaerella fijiensis, causal agent of black Sigatoka, to propiconazole. Phyto- pathology 87:96-100.

23. Valsesia, G., Gobbin, D., Patocchi, A., Vecchione, A., Pertot, I., and Gessler, C. 2005. Development of a high-throughput method for quantification of Plasmopara viticola DNA in grapevine leaves by means of quantitative real-time polymerase chain reaction. Phytopathology 95:672678.

24. Vandermark, G. J., and Barker, B. M. 2003. Quantifying the relationship between disease severity and the amount of Aphanomyces euteiches in roots of alfalfa and pea with a real-time PCR assay. Archiv. Phytopathol. Plant Prot. 36:81-93.

25. Waalwijk, C., van der Heide, R., de Vries, I., van der Lee, T., Schoen, C., Costrel-de Corainville, G., Häuser-Hahn, I., Kastelein, P., Köhl, J, Lonnet, P., Demarquet, T., and Kema, G. H. J. 2004. Quantitative detection of Fusarium species in wheat using TaqMan. Eur. J. Plant Pathol. 110:481494.

26. Winton, L. M., Stone, J. K., Watrud, L. S., and Hansen, E. M. 2002. Simultaneous one-tube quantification of host and pathogen DNA with real-time polymerase chain reaction. Phytopathology 92:112-116. 